\title{
Spontaneously Ruptured Giant Splenic Cyst with Elevated Serum Levels of CA 19-9, CA 125 and Carcinoembryonic Antigen
}

\author{
Takamitsu Inokuma Shigeki Minami Kazuo Suga \\ Yoshiteru Kusano Kenya Chiba Masato Furukawa \\ Department of Surgery, Nishi Isahaya Hospital, Isahaya, Japan
}

\section{Key Words}

Splenic cyst · Rupture - Carbohydrate antigen 19-9 - Cancer antigen 125 .

Carcinoembryonic antigen

\begin{abstract}
Splenic cyst is a relatively rare disease; however, the occurrence of complications associated with its rupture is even more rare. A 20-year-old female patient who had severe abdominal and left shoulder pain was admitted to our hospital. The patient's abdomen was hard and tender to the touch and she presented with a high fever. The patient's serum levels of the tumor markers carbohydrate antigen 19-9, cancer antigen 125 and carcinoembryonic antigen were high. Ultrasonography and computed tomography of the abdomen showed an $11-\mathrm{cm}$ multilocular cystic lesion in the spleen and the presence of free intraperitoneal fluid. Peritonitis with ruptured splenic cyst was diagnosed, and the patient underwent an emergency laparotomy. The abdominal cavity was filled with purulent fluid. The cyst was localized to the spleen and had already ruptured. Total splenectomy and cyst resection were performed. The postoperative course was uneventful. The patient was discharged on day 9 following surgery. The histological findings showed the lesion to be a benign epidermoid cyst completely lined with inner stratified squamous epithelium with a capsule of connective tissue. In the immunostaining analyses, the squamous epithelium was positive for carcinoembryonic antigen. A ruptured splenic cyst causes sudden onset of severe peritonitis and elevation of serous tumor markers. An emergency operation is indicated as the treatment for a ruptured splenic cyst with peritonitis, after which a favorable outcome can be expected.
\end{abstract}




\section{Introduction}

Splenic cyst is a relatively rare occurrence. Recently, several cases of splenic cyst with high serum levels of carbohydrate antigen 19-9 (CA 19-9), cancer antigen 125 (CA 125) and carcinoembryonic antigen (CEA) have been reported. It has been suggested that the cysts are produced by the inner epithelium of the cyst. Splenic cysts are mostly asymptomatic but become symptomatic as a consequence of enlargement, infection, or rupture, which are very rare complications. Spontaneous or traumatic rupture constitutes an absolute indication for surgery. We herein report a patient with a spontaneously ruptured splenic cyst with high serum levels of CA 19-9, CA 125 and CEA who was successfully treated by emergency operation.

\section{Case Report}

A 20-year-old female patient suffered from severe abdominal and left shoulder pain and was admitted to our hospital the next day. At the time of admission, her body temperature was $38.5^{\circ} \mathrm{C}$. Her other vital signs (heart rate, blood pressure, respiratory rate and consciousness level) were stable, and her abdomen was hard and tender the touch. Rebound tenderness was observed, and the findings on physical examination suggested peritonitis. There were no remarkable findings in the chest, neck, or shoulder. The patient's past medical history was unremarkable, and she did not report any abdominal trauma. Laboratory data showed inflammatory findings (white blood cell count 9,300/ $\mu$ and C-reactive protein $7.80 \mathrm{mg} / \mathrm{dl}$ ). There was no anemia, and the patient had normal platelet counts. Liver and renal function tests and electrolyte analyses also revealed normal results. Serum concentrations of tumor markers were high, as follows: CEA, $135 \mathrm{ng} / \mathrm{ml}$ (normal <5.0 ng/ml), CA 19-9, 43,000 U/ml (normal $<37 \mathrm{U} / \mathrm{ml}$ ), and CA $125,1,470 \mathrm{U} / \mathrm{ml}($ normal $<35 \mathrm{U} / \mathrm{ml})$.

Since the patient was hemodynamically stable, further studies with ultrasonography and computed tomography of the abdomen to the pelvis were performed. Ultrasonography and computed tomography showed an 11-cm multilocular cystic lesion in the spleen and the presence of free intraperitoneal fluid (fig. 1). Peritoneal hypertrophy and a relatively high density of the connective tissue around the spleen were also observed. The patient was diagnosed with peritonitis and a ruptured splenic cyst, and she underwent emergency laparotomy via a midline incision.

The abdominal cavity was filled with purulent fluid. A giant cyst was present in the spleen and adhered to the abdominal surface of the left diaphragm. The cyst had already ruptured at the time of the laparotomy. The gastrointestinal tract, liver, gallbladder, pancreas, kidney, and genital organs were intact. Total splenectomy and cyst resection were performed (fig. 2). One part of the cystic wall that adhered to the diaphragm was burned with an argon beam coagulant. After operation, the patient was administered imipenem/cilastatin sodium. The patient's white blood cell count was elevated to $15,500 / \mu \mathrm{l}$ with a moderate fever on day 2 following the operation. Subsequently, her inflammatory reaction diminished. She was discharged on day 9 after surgery, and she remains healthy without episodes of recurrence.

The histological findings revealed that the lesion was a benign epidermoid cyst that was completely lined by inner stratified squamous epithelium and surround by a capsule of connective tissue (fig. $3 a$ ). No hair follicles or other dermal appendages were present. In the immunostaining analyses, the squamous epithelium was found to be positive for CEA (fig. 3b). The level of CEA in the ascites at the time of the operation was extremely high $(7,700 \mathrm{ng} / \mathrm{ml})$. The ascites culture showed no bacterial growth. The ascites cytological analyses revealed no malignant cells. On the 9th day after the operation, the serum concentrations of tumor markers were drastically decreased in comparison to the levels measured at the time of admission, as follows: CEA, $17.8 \mathrm{ng} / \mathrm{ml}$, and CA 19-9, 4,630 U/ml.

\section{Discussion}

Splenic cysts are a relatively rare event, with an incidence of $0.07 \%$ as reported in a review of 42,327 autopsies [1]. Recent advances in medical imaging have contributed to an increase in the detection of occult splenic cysts. Splenic cysts are classified as primary 
or secondary cysts, depending on the presence or absence of an epithelial lining of the lumen [2]. Primary cysts are further divided into parasitic and nonparasitic types. Most parasitic cysts occur as a result of infection by Taenia echinococcus. Secondary cysts are caused by trauma, infarcts, or infections. The optimal treatment of splenic cysts remains controversial, and standard guidelines have not yet been established. If the cyst is smaller than $5 \mathrm{~cm}$ in diameter and asymptomatic, no treatment is necessary [2]. Cysts larger than $5 \mathrm{~cm}$ in diameter or symptomatic cysts require treatment. However, the reasoning for a $5-\mathrm{cm}$ diameter cutoff appears to be unclear. In the present case, the histological findings revealed squamous epithelial lining of the lumen. Therefore, the cyst was diagnosed as a primary cyst. Infection by Taenia echinococcus was not found, and the cyst was therefore suspected to be of nonparasitic origin.

Although some treatments (aspiration, injection, fenestration, and splenectomy) are sometimes performed for splenic cysts, total or partial splenectomy is generally chosen by the physician. Recurrent postaspiration and malignancy cases have been reported $[3,4]$. Since the spleen is essential for the control of blood volume and the immune system, partial splenectomy is recommended if possible. Recently, a laparoscopic splenectomy has been performed [5]. In the present case, an emergency surgical procedure was performed due to the large cyst size $(11 \mathrm{~cm}$ in diameter) and because the patient had complained of severe abdominal pain with a high fever, suggesting peritonitis. As the splenic cyst had already ruptured, emergency total splenectomy was able to successfully treat the patient's critical condition.

Ruptured splenic cysts are an extremely rare complication in splenic cysts. Only 13 cases of ruptured splenic cysts have been reported (table 1) [5-17]. In those studies, the mean age of the patients was 20.0 years (range 9-36 years), and the mean diameter of the cysts was $8.6 \mathrm{~cm}$ (range $4-14 \mathrm{~cm}$ ) in diameter. In most cases, the patients complained of abdominal pain, sometimes accompanied by left shoulder pain or vomiting. The free peritoneal fluid that tended to accompany a ruptured splenic cyst was useful for the diagnoses. Total splenectomy was performed in all cases but one. Fenestration was performed in one case. The splenic cyst ruptures required emergency operative therapy, and the postoperative courses were mostly uneventful.

The mechanisms involved in splenic cyst rupture are currently unknown. Trauma, infection, or an increase in the cystic component may trigger such rupture. Free peritoneal fluid and purulence were observed in one previous case and in the present patient [12]. It is known that splenic abscess follows sepsis (bacterial endocarditis, malaria, and urinary tract infections, among other causes), but the infectious route resulting in splenic cysts is unknown.

Serum concentrations of tumor markers (for example, CEA, CA 19-9, and CA 125) were elevated in several patients with splenic cysts [18]. In spite of high levels of tumor markers, no malignancy was seen in the current patient. Tumor markers are hypothesized to be secreted into the intracystic fluid by the inner epithelial cells originating from the cysts. In the immunohistochemical staining, the epithelial cells were found to be positive for tumor markers. Since cysts are closed cavities, intracystic tumor markers become more concentrated over time. Several mechanisms that are not yet characterized may induce the transport of intracystic tumor markers into dynamic circulation. Rupture may be one drastic mechanism by which this is accomplished. Intracystic tumor markers that are distributed in the free peritoneal cavity are absorbed through the peritoneum, and the serous levels of tumor markers are thereby increased. Only one patient with a ruptured splenic cyst and elevated serous tumor markers has been previously reported; the present case is the second patient described in the literature [16]. In general, the serous levels of 
tumor markers in patients with splenic cysts are rapidly reduced after resection, and our patient showed a similar course.

\section{Conclusions}

Splenic cysts are a relatively rare event; moreover, complications due to rupture are extremely rare. A ruptured splenic cyst causes sudden onset of severe peritonitis with elevated serous tumor markers. An emergency operation is the recommended treatment for patients with a ruptured splenic cyst and peritonitis, and this surgical treatment was very effective in the present patient. 
Table 1. Summary of case reports of ruptured splenic cyst

\begin{tabular}{|c|c|c|c|c|c|c|c|c|c|c|c|}
\hline \multirow[t]{2}{*}{ Ref. } & \multirow[t]{2}{*}{ Year } & \multirow[t]{2}{*}{ Age } & \multirow[t]{2}{*}{ Sex } & \multirow[t]{2}{*}{ Complaint } & \multirow{2}{*}{$\begin{array}{l}\text { Size } \\
(\mathrm{cm})\end{array}$} & \multirow{2}{*}{$\begin{array}{l}\text { Operation } \\
\text { method }\end{array}$} & \multirow{2}{*}{$\begin{array}{l}\text { Free } \\
\text { peritoneal } \\
\text { fluid }\end{array}$} & \multicolumn{2}{|c|}{ Tumor marker } & \multirow{2}{*}{$\begin{array}{l}\text { Pathological } \\
\text { diagnosis }\end{array}$} & \multirow{2}{*}{$\begin{array}{l}\text { Postop. } \\
\text { compli- } \\
\text { cation }\end{array}$} \\
\hline & & & & & & & & serous & $\begin{array}{l}\text { intracystic } \\
\text { fluid }\end{array}$ & & \\
\hline [6] & 1960 & 17 & $\mathrm{~F}$ & $\begin{array}{l}\text { abdominal } \\
\text { pain, vomiting }\end{array}$ & 10 & $\begin{array}{l}\text { total } \\
\text { splenectomy }\end{array}$ & $\begin{array}{l}\text { large amount } \\
\text { of blood }\end{array}$ & N/A & N/A & $\begin{array}{l}\text { epidermoid } \\
\text { cyst }\end{array}$ & none \\
\hline [7] & 1963 & 9 & M & $\begin{array}{l}\text { left hypo- } \\
\text { chondralgia, } \\
\text { nausea }\end{array}$ & 12 & $\begin{array}{l}\text { total } \\
\text { splenectomy }\end{array}$ & none & N/A & N/A & $\begin{array}{l}\text { epidermoid } \\
\text { cyst }\end{array}$ & $\begin{array}{l}\text { acute } \\
\text { retention } \\
\text { of urine }\end{array}$ \\
\hline$[8]$ & 1965 & 15 & M & $\begin{array}{l}\text { chest and back } \\
\text { pain, headache }\end{array}$ & 9 & $\begin{array}{l}\text { total } \\
\text { splenectomy }\end{array}$ & N/A & N/A & N/A & $\begin{array}{l}\text { epidermoid } \\
\text { cyst }\end{array}$ & none \\
\hline [9] & 1967 & 10 & M & $\begin{array}{l}\text { abdominal } \\
\text { pain, fever }\end{array}$ & 7 & $\begin{array}{l}\text { total } \\
\text { splenectomy }\end{array}$ & N/A & N/A & N/A & $\begin{array}{l}\text { epidermoid } \\
\text { cyst }\end{array}$ & $\begin{array}{l}\text { discharge } \\
\text { with drain }\end{array}$ \\
\hline [10] & 1970 & 14 & $\mathrm{~F}$ & $\begin{array}{l}\text { abdominal } \\
\text { pain }\end{array}$ & 6 & $\begin{array}{l}\text { total } \\
\text { splenectomy }\end{array}$ & existence & N/A & N/A & $\begin{array}{l}\text { epidermoid } \\
\text { cyst }\end{array}$ & none \\
\hline$[11]$ & 1983 & 14 & M & $\begin{array}{l}\text { abdominal } \\
\text { pain }\end{array}$ & $11 \times 7$ & $\begin{array}{l}\text { total } \\
\text { splenectomy }\end{array}$ & $\begin{array}{l}1,500 \mathrm{ml} \text {, } \\
\text { blood }\end{array}$ & N/A & N/A & $\begin{array}{l}\text { epithelial } \\
\text { cyst }\end{array}$ & none \\
\hline$[12]$ & 1990 & 20 & M & $\begin{array}{l}\text { abdominal } \\
\text { pain }\end{array}$ & $5.5 \times 4.0$ & $\begin{array}{l}\text { total } \\
\text { splenectomy }\end{array}$ & $\begin{array}{l}500 \mathrm{ml}, \\
\text { pus }\end{array}$ & N/A & N/A & $\begin{array}{l}\text { epidermoid } \\
\text { cyst }\end{array}$ & none \\
\hline [13] & 1991 & 15 & $\mathrm{~F}$ & $\begin{array}{l}\text { abdominal } \\
\text { pain, nausea, } \\
\text { vomiting }\end{array}$ & 12 & $\begin{array}{l}\text { total } \\
\text { splenectomy }\end{array}$ & existence & N/A & N/A & $\begin{array}{l}\text { epidermoid } \\
\text { cyst }\end{array}$ & none \\
\hline$[14]$ & 1996 & 9 & M & $\begin{array}{l}\text { abdominal } \\
\text { pain, vomiting }\end{array}$ & 7 & fenestration & none & N/A & N/A & $\begin{array}{l}\text { epidermoid } \\
\text { cyst }\end{array}$ & none \\
\hline [15] & 1998 & 34 & M & $\begin{array}{l}\text { epigastric pain, } \\
\text { left shoulder } \\
\text { pain }\end{array}$ & 5 & $\begin{array}{l}\text { total } \\
\text { splenectomy }\end{array}$ & $\begin{array}{l}600 \mathrm{ml}, \\
\text { blood }\end{array}$ & N/A & N/A & $\begin{array}{l}\text { mesothelial } \\
\text { cyst }\end{array}$ & none \\
\hline [16] & 2001 & 36 & $\mathrm{~F}$ & $\begin{array}{l}\text { left hypo- } \\
\text { chondralgia }\end{array}$ & $14 \times 9 \times 7$ & $\begin{array}{l}\text { total } \\
\text { splenectomy }\end{array}$ & none & $\begin{array}{l}\text { CEA 8.3, } \\
\text { CA 19-9 } \\
>24,000 \text {, } \\
\text { SLx } 112.9\end{array}$ & $\begin{array}{l}\text { CEA 3,417, } \\
\text { CA 19-9 } \\
>24,000\end{array}$ & $\begin{array}{l}\text { epidermoid } \\
\text { cyst }\end{array}$ & none \\
\hline$[5]$ & 2005 & 32 & $\mathrm{~F}$ & $\begin{array}{l}\text { abdominal } \\
\text { pain, left } \\
\text { shoulder pain }\end{array}$ & $9 \times 6$ & $\begin{array}{l}\text { total } \\
\text { splenectomy }\end{array}$ & existence & N/A & N/A & $\begin{array}{l}\text { epidermoid } \\
\text { cyst }\end{array}$ & N/A \\
\hline [17] & 2006 & 35 & $\mathrm{~F}$ & $\begin{array}{l}\text { upper } \\
\text { abdominal pain }\end{array}$ & 4 & $\begin{array}{l}\text { total } \\
\text { splenectomy }\end{array}$ & $\begin{array}{l}\text { small amount } \\
\text { of blood }\end{array}$ & N/A & N/A & $\begin{array}{l}\text { true } \\
\text { splenic cyst }\end{array}$ & none \\
\hline $\begin{array}{l}\text { Our } \\
\text { case }\end{array}$ & 2010 & 20 & F & $\begin{array}{l}\text { abdominal } \\
\text { pain, left } \\
\text { shoulder pain }\end{array}$ & 11 & $\begin{array}{l}\text { total } \\
\text { splenectomy }\end{array}$ & pus & $\begin{array}{l}\text { CEA 135, } \\
\text { CA 19-9 } \\
43,000, \\
\text { CA } 1251,470\end{array}$ & N/A & $\begin{array}{l}\text { epidermoid } \\
\text { cyst }\end{array}$ & none \\
\hline
\end{tabular}

CEA = Carcinoembryonic antigen; CA 19-9 = carbohydrate antigen 19-9; CA $125=$ cancer antigen 125; SLx = Sialyl Lewis $\mathrm{x}$; N/A = not available. 


\begin{tabular}{r|l|l|l}
$\begin{array}{r}\text { Case Reports in } \\
\text { Gastroenterology }\end{array}$ & $\begin{array}{l}\text { Case Rep Gastroenterol 2010;4:191-197 } \\
\text { D0I: 10.1159/000315559 }\end{array}$ & Published online: June 11, 2010 & $\begin{array}{l}\text { @ 2010 S. Karger AG, Basel } \\
\text { ISSN 1662-0631 } \\
\text { www.karger.com/crg }\end{array}$ \\
\hline
\end{tabular}

Fig. 1. The computed tomography findings showed a cystic lesion in the spleen and the presence of free intraperitoneal fluid.

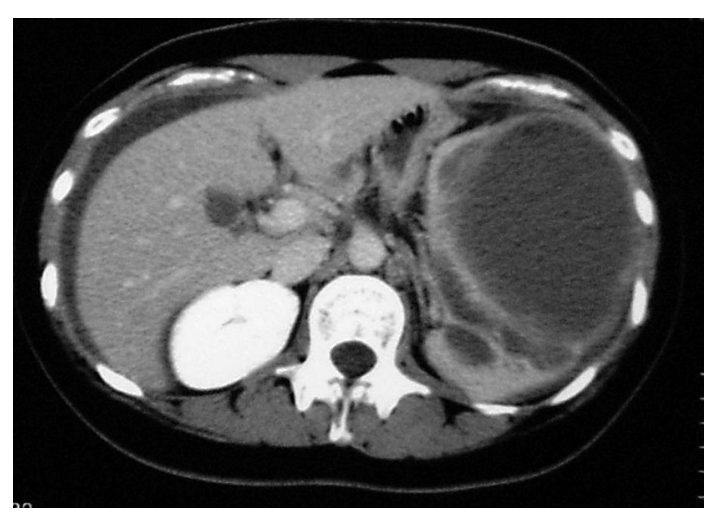

Fig. 2. A cystic lesion was found in the spleen.

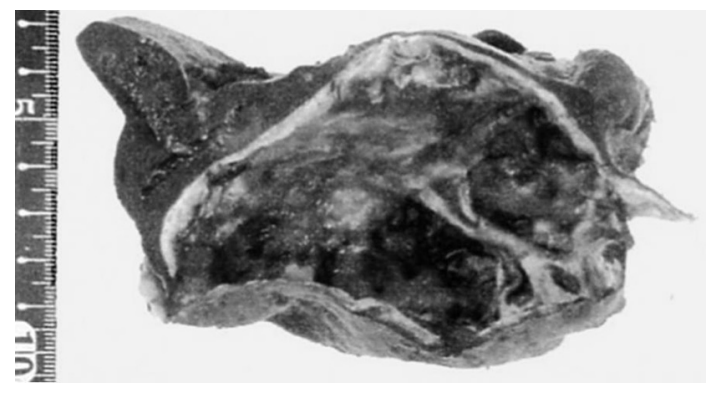

Fig. 3. a The histological findings of the resected specimen showed squamous epithelium lining the lumen. $\mathbf{b}$ In the immunostaining analyses, the squamous epithelium was positive for CEA.
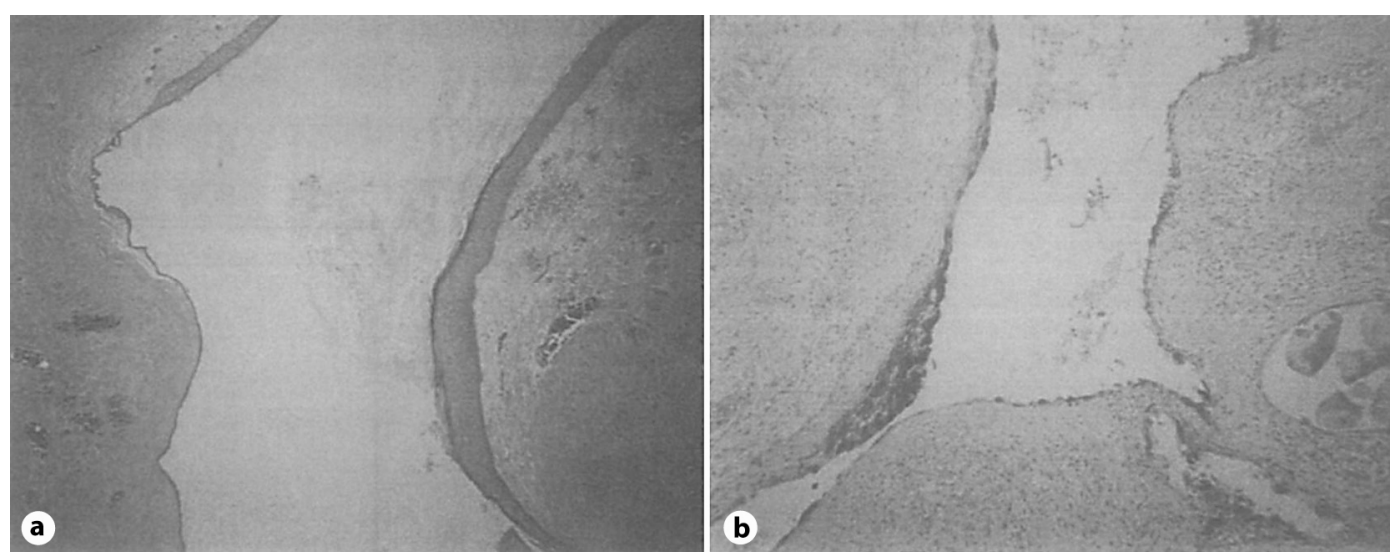


\section{References}

1 Robbins FG, Yellin AE, Lingua RW, Craig JR, Turrill FL, Mikkelsen WP: Splenic epidermoid cysts. Ann Surg 1978;187:231-235.

2 Hansen MB, Moller AC: Splenic cysts. Surg Laparosc Endosc Percutan Tech 2004;14:316-322.

-3 Kaiwa Y, Kurokawa Y, Namiki K, Matsumoto H, Satomi S: Laparoscopic partial splenectomies for true splenic cysts. A report of two cases. Surg Endosc 2000;14:865.

4 Elit L, Aylward B: Splenic cyst carcinoma presenting in pregnancy. Am J Hematol 1989;32:57-60.

5 Kiriakopoulos A, Tsakayannis D, Papadopoulos S, Linos S: Laparoscopic management of a ruptured giant epidermoid splenic cyst. JSLS 2005;9:349-351.

6 Coleman WO: Epidermoid cyst of the spleen. Report of two cases. Am J Surg 1960;100:475-479.

7 Browne MK: Epidermoid cyst of the spleen. Br J Surg 1963;50:838-841.

8 Dibble JB, Weigent CE: Epidermoid cyst of the spleen presenting as an abdominal emergency. JAMA 1965;194:1144-1146.

-9 Lippitt WH, Akhavan T, Caplan GE: Epidermoid cyst of the spleen with rupture and inflammation. Arch Surg 1967;95:74-78.

10 Watkins GL: Epidermoid cyst of the spleen with spontaneous rupture and massive hemoperitoneum. Mo Med 1970;67:106-107.

11 Spence RAJ, Dane TEB: Spontaneous rupture of an epithelial cyst of the spleen. Postgrad Med J 1983;59:65.

12 Panossian DH, Wang N, Reeves CD, Weeks DA: Epidermoid cyst of the spleen presenting as a generalized peritonitis. Am Surg 1990;56:295-298.

13 Rathaus V, Zissin R, Goldberg E: Spontaneous rupture of an epidemoid cyst of spleen: preoperative ultrasonographic diagnosis. J Clin Ultrasound 1991;19:235237.

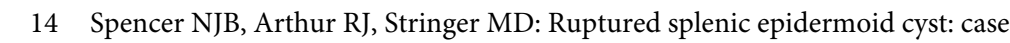
report and imaging appearances. Pediatr Radiol 1996;26:871-873.

15 Lam CM, Yuen ST, Yuen WK: Hemoperitoneum caused by spontaneous rupture of a true splenic cyst. Hepatogastroenterology 1998;45:1884-1886.

16 Matusbayashi H, Kuraoka K, Kobayashi Y, Yokota T, Iiri Y, Shichijo K, Tada T, Satoh K, Kijima H: Ruptured epidermoid cyst and haematoma of spleen: a diagnostic clue of high levels of serum carcinoembryonic antigen, carbohydrate antigen 19-9 and Sialyl Lewis x. Dig Liver Dis 2001;33:595-599.

17 Karasakalides A, Ganas E, Triantafillidou S, Lagonidis D, Papapavlou L, Nakos G: Spontaneous rupture of a true splenic cyst diagnosed by laparoscopy. Dig Dis Sci 2006;51:1829-1832.

18 Sardi A, Ojeda HF, King D: Laparoscopic resection of a benign true cyst of the spleen with the harmonic scalpel producing high levels of CA 19-9 and carcinoembryonic antigen. Am Surg 1998;64:1149-1154. 